Poulos, H. G. (1968). Analysis of the settlement of pile groups. Géotechnique 18, No. 4, 449-471.

Poulos, H. G. (1974). Some recent developments in the theoretical analysis of pile behaviour. Soil mechanics -new horizons, 237-279. Ed. I. K. Lee. London: Butterworths.

Poulos, H. G. \& Mattes, N. S. (1971). Settlement and load distribution of pile groups. Aust. Geomech. Jnl G1, No. 1, 18-28.

\title{
Boundary wedges in two-dimensional passive soil failure
}

\author{
HETTIARATCHI, D. R. P. and REECE, A. R. (1975). Géotechnique 25, No. 2, 197-220.
}

\section{J. L. Justo, ETS Arquitectura, University of Seville}

Hettiaratchi and Reece state that all the assumptions and limitations specified under the section 'Basic assumptions' in their 1974 paper also apply to the present analysis. In the quoted paper they say, 'Soil obeys the associated flow rule of the theory of plasticity and the velocity field corresponds to the stress field.'

Although the Authors make the lower side of the kinematic wedge (slip line) parallel to the direction of the interface movement, it is clear that they are actually considering a nondilating $(\nu=0)$ material. On the other hand, they make this slip line coincide with a stress characteristic. This kind of behaviour might occur in materials at the critical state (Salas and Justo, 1971; Mandl, 1971).

Near the tip of the interface the critical state must have been reached at peak passive pressure, owing to the large shear strains (Rowe and Peaker, 1965; Kérisel, 1972; Bassett, 1972).

All the experimental evidence quoted by the Authors actually sustains the $\nu=0$ hypothesis near the tip of the interface. In the tests performed by Rowe and Peaker (1965) and Rowe (1969) on translating walls it is possible to follow the mobilization of $\delta$ with wall movement. In Fig. 1 the values of $\delta$ corresponding to maximum passive pressure have been drawn as a function of the direction of translation of interface, and are compared with the line obtained

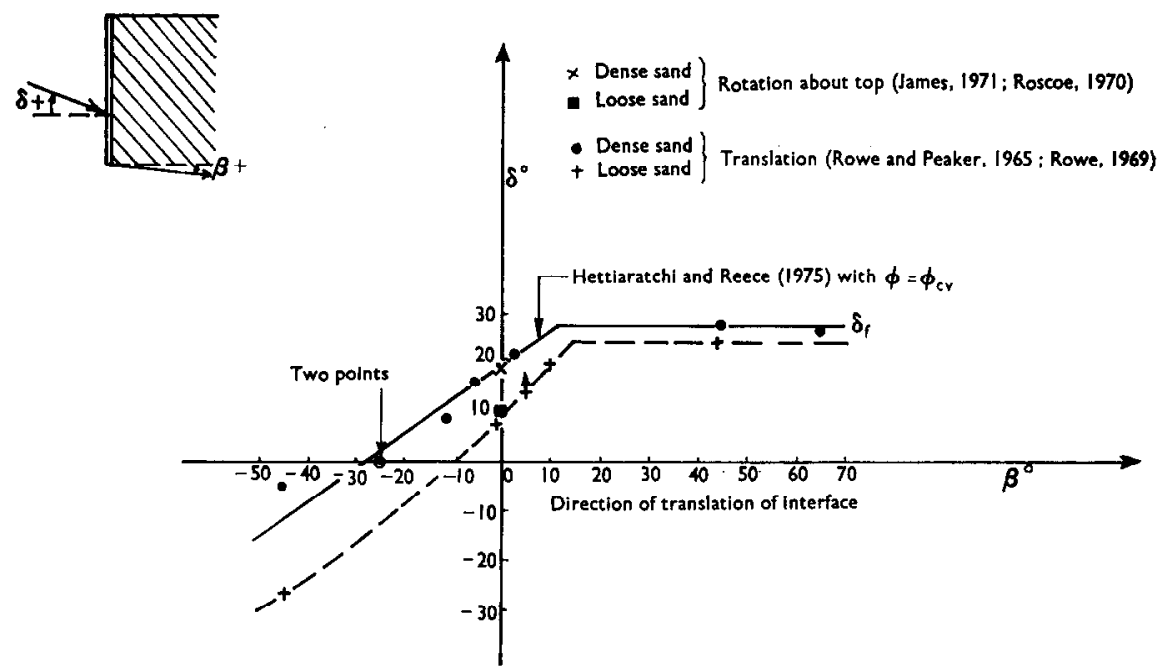

Fig. 1. Comparison of measurements of $\delta$ and theory assuming critical state and coincidence of slip surface and stress characteristic at interface 
from the Paper, but making $\phi=\phi_{\mathrm{cv}}$. The agreement is good for dense sand. The Authors include more measured $\delta$ values to sustain their theory, although they do not state whether they actually correspond to the maximum passive pressure.

Actually, the $\delta$ values of Fig. 1 for dense sand should correspond only to the tip of the interface. But several researchers have found that for a translating wall there is a quasi-linear distribution of stresses along the wall (Rowe and Peaker, 1965; Roscoe, 1970; Tcheng and Iseux, 1972). This kind of distribution entails a constant $\delta$ value along the interface (Roscoe, 1970).

In several other cases, for a vertical interface and horizontal translation, average $\delta$ values between $28^{\circ}$ and $30^{\circ}$ have been measured at peak passive pressure (Roscoe, 1970; Bassett, 1972; Kérisel, 1972). These are the values obtained if the slip line at the tip of the interface is a zero extension line. $\quad \nu=0$, and coaxiality is assumed (Lee and Herington, 1972). Another possible explanation is a non-uniform distribution of $\delta$ along the wall (Butterfield et al., 1973).

As stated by the Authors, the $\delta$ values measured in loose sands are much less than the ones obtained by either theory (Fig. 1). The average $\delta$ values measured at peak passive pressure for rotation about the top are included in Fig. 1. The coincidence with translation is striking. I have measured and averaged the angle of intersection of the lower rupture surface with the soil surface from the Authors' Figs 9 and 11. For both polished and rough ${ }^{1}$ blade surface this angle is $41^{\circ}$. A rational explanation is that the rupture surface is zero extension line with $\nu=8^{\circ}$, and there is coaxiality between stress and strain increment at that zone. I have also measured the angle formed by the kinematic wedge pseudo-interface with the horizontal (Authors' Figs 10 and 12). This angle is about $69^{\circ}$ for both polished and rough blades. If we assume that it is a zero extension line, $\nu \simeq 21^{\circ}$, but if we assume that it is a stress characteristic this value would correspond to $\phi$, and that is not feasible.

To summarize, the scarce data collected up to now about the average $\delta$ developed by a translating wall at peak passive pressure in dense sand is somewhere between the value obtained by the Authors' theory with $\phi=\phi_{\mathrm{cv}}$ and the one obtained from Lee and Herington (1972). However, it seems that the slip lines are zero extension lines with different values of $\mu$ : a low value at the lower rupture surface, becoming zero at the tip of the interface due to the large shear strains, but reaching the maximum value everywhere else (Butterfield et al., 1973).

\section{REFERENCES}

Bassett, R. H. (1972). Discussions. Sth European Conf. Soll Mech., Madrid 2, 152-154.

Butterfield, R., Harkness, R. M. \& Andrawes, K. Z. (1973). Idealized granular materials. Symp. Plasticity and Soil Mech., Cambridge, 174-185.

James, R. G. (1971). Some aspects of soil mechanics model testing. Stress-strain behaviour of soil, 417-440, Henley-on-Thames: Foulis.

Kérisel, J. (1972). Le langage des modèles en mécanique des sols. 5th European Conf. Soil Mech., Madrid 2, 9-30.

Lee, I. K. \& Herington, J. R. (1972). Effect of wall movement on active and passive pressures. Jnl Soil Mech. Fdn Am. Soc. Civ. Engrs 98, SM6, 625640.

Mandl, G. (1971). Discussions. Stress-strain behaviour of soils, 493 . Henley-on-Thames: Foulis.

Roscoe, K. H. (1970). The influence of strains in soils mechanics. Géotechnique 20, No. 2, 129-170.

Rowe, P. W. (1969). Progressive failure and strength of a sand mass. 7th Int. Conf. Soil Mech. Fdn Engng, Mexico 1, 341-349.

Rowe, P. W. \& Peaker, K. (1965). Passive earth pressure measurements. Géotechnique 15, No. 1, 57-78.

Salas, J. A. J. \& Justo, J. L. (1971). Geotécnica y cimientos 1. Propiedades de los suelos y de las rocas. Madrid: Rueda.

Tcheng, Y. \& Iseux, J. (1972). Essais de butée en vrai grandeur et contraintes engendrées par une surcharge rectangulaire sur un mur vertical. 5th European Conf. Soil Mech., Madrid 1, 207-214.

\footnotetext{
${ }^{1}$ In this last case, the values for rake angles up to $40^{\circ}$ (not common in foundations) have been rejected.
} 